\title{
Acute Toxicity and Sedative-hypnotic Effects of Ethanol Stem Bark Extract and Fractions of Milicia excelsa (Moraceae) in Mice
}

\author{
Akinpelu Lateef Abiola ${ }^{1, *}$, Adebayo Muritala Ayofe ${ }^{2}$, Aiyelero Oyeronke Medinat ${ }^{3}$, Ogundepo Gbenga \\ Emmanuel $^{4}$, Fajana Akibu ${ }^{2}$, Isede Nwamaka Ruthlyn ${ }^{2}$, Akinbiyi Ireyemi Abisoye ${ }^{2}$, Sani Abdulrahman \\ Ibrahim $^{2}$
}

\begin{abstract}
${ }^{1}$ Department of Pharmacology and Toxicology, Dora Akunyili College of Pharmacy, Igbinedion University, Nigeria
${ }^{2}$ Department of Pharmacognosy, Dora Akunyili College of Pharmacy, Igbinedion University, Nigeria

${ }^{3}$ Department of Pharmacology and Toxicology, Faculty of Pharmaceutical Sciences, University of Ilorin, Nigeria

${ }^{4}$ Department of Biochemistry, Faculty of Science, Obafemi Awolowo University, Ile-Ife, Nigeria
\end{abstract}

Received December 29, 2019; Revised February 7, 2020; Accepted February 18, 2020

Copyright $\odot 2020$ by authors, all rights reserved. Authors agree that this article remains permanently open access under the terms of the Creative Commons Attribution License 4.0 International License

\begin{abstract}
Aim: Milicia excelsa stem bark is used as sedative and for treating mental illnesses among the Hausa tribe of Northern Nigeria, but there is no scientific rationale for its use. Hence, this study investigated the oral acute toxicity and sedative potential of ethanol stem bark extract, n-hexane, ethylacetate, n-butanol and aqueous fractions of the stem bark extract in mice. The phytoconstituents in the extract and fractions were quantified. Methodology: The acute toxicity of the extract and fractions were investigated using OECD guidelines 425 of 2008. The sedative effects of the extract and fractions were investigated using pentobarbital-, and ketamine-induced sleep tests. Results and discussion: The results obtained showed that the acute toxicity of the extract and fractions were $\geq 5000 \mathrm{mg} / \mathrm{kg}$, suggesting that the extract and fractions may be safe. The extract, n-hexane, ethylacetate and aqueous fractions significantly $(\mathrm{p}<0.05)$ reduced sleep latencies, indicative of sedative effects, effective for sleep induction, while the extract and all the fractions significantly $(\mathrm{p}<0.05)$ prolonged the sleep durations, suggesting sedative effects, effective for sleep maintenance. Conclusion: This study therefore, concluded that the extract and fractions may be safe. The study further concluded that the sedative effect of the extract and fractions may be due to the abundance of flavonoids in the extract and fractions. Thus, providing scientific rationale for its ethnomedicinal use. However, further study may be warranted to isolate and characterize the sleep promoting bioactive principles as well as carry out GABA binding assay of the isolated compound(s) in ESB and its various fractions.
\end{abstract}

Keywords Milicia excelsa, Sedative, Ketamine,
Pentobarbitone, GABA

\section{Introduction}

Insomnia is one of the ailments which affects people of all ages worldwide [1]. It is often defined as sleeping problems which is characterized by difficulty in falling asleep (sleep induction), continuing asleep (sleep maintenance) or as having non refreshing sleep to a certain extent [2].

Insomnia can be treated pharmacologically, non-pharmacologically, or by the combination of the two [3]. The non pharmacological treatments is also known as behavioural therapies, which include relaxation, sleep restriction, stimulus control and sleep hygiene, while the pharmacological treatments involve prescription drugs such as benzodiazepines [4] or newer non benzodiazepines $[5,6]$.

Despite reported clinical success, these medications have in attendance side effects such as physical dependence [7], daytime fatigue [8], cognitive impairment [9] and non-effective response to the existing therapeutic drugs by some patients with sleep problems [10]. In order to circumvent these undesirable effects, scientists have resorted to alternative therapy that could improve sleep quality as well as devoid of undesirable effects [11]. This is evident from the previous studies of herbal drugs with promising sedative-hypnotic effect [12].

Milicia excelsa (welw.) C.C. Berg, otherwise known as 
Chlorophora excelsa, is a large deciduous tree growing up to the height of $50 \mathrm{~m}$. It is naturally found in the humid forest of the West Africa sub-region [13]. It belongs to the mulberry family (Moraceae) and popularly called Iroko tree or African teak [13]. The different plant parts of Milicia excelsa are used in ethnomedicines to prepare herbal remedies in African traditional settings [14]. For example the stem bark is used as sedative and for the treatment of mental illnesses [15] such as convulsion [16] and psychosis [17]. Pharmacologically, the antipsychotic [18], anticonvulsant [19], anti-stress [20], antiamnesic [21] and wound healing effects [22] of the leaf have been scientifically evaluated. The anti-inflammatory effect of the stem bark [23] and the antidiarrheal effect of the root bark [24] have also been scientifically validated.

Consequent on its use as sedative among the Hausa tribe of Northern Nigeria [15], this study was designed to investigate the sedative effect of the ethanol stem bark extract and fractions in mice.

\section{Materials and Methods}

\subsection{Plant Identification and Authentication}

Milicia excelsa stem bark was collected within the campus of Obafemi Awolowo University (OAU), Ile Ife. It was identified and authenticated by Mr. G. A. Ademoriyo of the Herbarium Unit, Department of Botany, Faculty of Sciences of the Obafemi Awolowo University, Ile-Ife Nigeria and herbarium number Ife-17482 was obtained.

\subsubsection{Preparation of Plant Materials}

The stem bark was cut into pieces and air dried at room temperature for two weeks. The dried stem barks were ground into powder by mechanical grinder and $8.29 \mathrm{~kg}$ of the powder was extracted by cold maceration with 15 litres of seventy percent (70\%) ethanol for $48 \mathrm{hr}$. The extract was concentrated in vacuo at a temperature of $40^{\circ} \mathrm{C}$ and freeze dried to yield $220.7 \mathrm{~g}(2.65 \%)$ crude extract and coded ESB. Two hundred gram (200 g) of the crude extract was successively partitioned into n-hexane, ethylacetate, n-butanol and aqueous fractions. The fractions were again concentrated in vacuo to give n-hexane fraction (HF 9.2 g, 4.6\%), ethyl-acetate fraction (EAF $20.8 \mathrm{~g}, 10.4 \%$ ), n- butanol fraction (BF $12 \mathrm{~g}, 6 \%$ ) and aqueous fraction (AF $19 \mathrm{~g}, 9.5 \%$ ).

\subsection{Drugs}

Diazepam (Roche, Basel, Switzerland), Pentobarbital sodium, Tween 80 (Sigma Aldrich, USA), Ketamine hydrochloride (Rotex Medica Tritau, Germany), and normal saline (Unique Pharmaceutical Limited, Lagos, Nigeria). The ESB and its various fractions were dissolved with 3\% Tween 80 and made up to the required volume with normal saline. The extract and its fractions were freshly prepared on each day of the experiment prior to ingestion to mice.

\subsection{Laboratory Animals}

Adult albino mice of both sexes (18-25 g) were obtained from the Central Animal House of the Igbinedion University, Okada, Edo State. The mice were maintained on standard animal pellets and water ad libitum. The experimental procedures adopted in this study followed the approved institutional animal ethical committee guidelines, which is in accordance with the internationally accepted principles for Laboratory Animal Use and Care [25].

\subsection{General Experimental Design}

Mice were randomized into 5 groups containing 5 mice per group $(n=5)$ as follows:

Group I (negative control group): mice in this group received $10 \mathrm{~mL} / \mathrm{kg}$ of the vehicle (3\% Tween 80 in normal saline).

Groups II-IV: mice in these groups received ESB at the 125, 250 and $500 \mathrm{mg} / \mathrm{kg}$ per oral respectively.

Groups V: mice in this group received the reference drug, diazepam (2 $\mathrm{mg} / \mathrm{kg}$, i.p.)

The experimental procedures above were repeated for HF, EAF, BF, and AF at the same doses as ESB.

Preliminary phytochemical quantifications

The total flavonoids, total phenols, tannin content and total alkaloids were quantitatively determined in ESB, HF, $\mathrm{EAF}, \mathrm{BF}$ and $\mathrm{AF}$ as previously described [26-29]. $\mathrm{n}=3$.

\subsection{Acute Toxicity Test}

The acute oral toxicity $\left(\mathrm{LD}_{50}\right)$ of ESB was investigated using the Organization for Economic Cooperation and Development (OECD) guidelines 425 of 2008 [26]. The acute toxicity test was conducted in two phases. In the first phase, a single female mouse was orally ingested with the extract at a dose of $2000 \mathrm{mg} / \mathrm{kg}$ per body weight of ESB after fasting for 3 hours. The mouse was observed for any signs of acute behavioural toxicity within the first $24 \mathrm{~h}$. From the result of the first phase; another 4 female mice were orally ingested with ESB at $2000 \mathrm{mg} / \mathrm{kg}$ per oral and subsequently observed for death in 24 hours and for any sign of delayed toxicity or death for the next 14 days. Based on the result of the second step, the two steps of the experiments were repeated for $5000 \mathrm{mg} / \mathrm{kg}$ per oral. The two phases as above were repeated for HF, EAF, BF, and AF. Thereafter the $\mathrm{LD}_{50}$ for each of the extract and fractions were determined.

\subsection{Sedative-hypnotic Experiments}




\subsubsection{Pentobarbital-induced Sleeping Test}

The effect ESB on pentobarbital-induced sleep test was carried out as previously done [31]. Mice were pretreated with ESB for 60 minutes or diazepam ( $2 \mathrm{mg} / \mathrm{kg}$, i.p.) for 30 minutes prior to the intraperitoneal injection of sodium pentobarbitone (30 mg/kg). The time in minutes between pentobarbitone injection and loss of righting reflex by each mouse was noted and taken as sleep latency (onset of sleep). The time duration between the loss and regain of righting reflex by each mouse was noted and taken as sleeping time. The procedures were repeated for HF, EAF, BF and AF respectively.

\subsubsection{Ketamine-induced Sleeping Time}

The effect ESB on ketamine-induced sleeping time was carried out as previously described [32]. Mice were pretreated with ESB for 60 minutes or diazepam $(2 \mathrm{mg} / \mathrm{kg}$, i.p.) for 30 minutes prior to the intraperitoneal injection of ketamine $(100 \mathrm{mg} / \mathrm{kg})$. The time in minutes between ketamine administration and loss of righting reflex by each mouse was noted and taken as sleep latency (onset of sleep). The time duration between the loss and regain of righting reflex by each mouse was noted and taken as sleeping time. The procedures were repeated for HF, EAF, BF and AF respectively.

\subsection{Statistical Analysis}

Results are expressed as mean \pm S.E.M. The significance of different between groups were analysed using one way analysis of variance (ANOVA), followed by Dunnett post hoc analysis using GraphPadInStat ${ }^{\circledR}$ Biostatistics software (GraphPad Software, Inc., La Jolla, USA). The level of significance for all tests was set at ${ }^{*} \mathrm{p}<0.05$.

\section{Results}

\subsection{Result of Preliminary Phytochemical Estimations of ESB and Its Fractions}

The result showed that total flavonoids in $\mathrm{ESB}>\mathrm{AF}>$ $\mathrm{EAF}>\mathrm{HF}>\mathrm{BF}$. The tannin content in $\mathrm{EAF}>\mathrm{AF}>\mathrm{ESB}>\mathrm{BF}>$ $\mathrm{HF}$. The total phenols in EAF $>\mathrm{AF}>\mathrm{ESB}>\mathrm{BF}>\mathrm{HF}$. The total alkaloids in $\mathrm{EAF}>\mathrm{AF}>\mathrm{ESB}>\mathrm{HF}>\mathrm{BF}$. The result also showed that total flavonoids is the most abundant in ESB while tannins, total phenols and total alkaloids are the most abundant in EAF. Of all the fractions, AF contained the most abundant total flavonoids, while EAF contained the most abundant of tannins, total phenols and total alkaloids. The result is presented in Table 1.

Table 1. Preliminary phytochemical estimations of ESB and its fractions

\begin{tabular}{|c|c|c|c|c|}
\hline Samples & $\begin{array}{c}\text { Total flavonoids(mg QUE/g } \\
\text { sample) }\end{array}$ & $\begin{array}{c}\text { Tannin content(mg GAE/g } \\
\text { sample) }\end{array}$ & $\begin{array}{c}\text { Total phenols(mg GAE/g } \\
\text { sample) }\end{array}$ & $\begin{array}{c}\text { Total alkaloids(mg AE/g } \\
\text { sample) }\end{array}$ \\
\hline ESB & $757.90 \pm 2.48$ & $83.19 \pm 0.80$ & $0.27 \pm 0.17$ \\
\hline HF & $363.16 \pm 20.31$ & $19.24 \pm 2.57$ & $87.60 \pm 0.75$ \\
\hline EAF & $610.53 \pm 25.18$ & $113.75 \pm 1.60$ & $1.33 \pm 0.06$ \\
\hline BF & $357.90 \pm 6.56$ & $55.46 \pm 2.01$ & $14.03 \pm 0.12$ \\
\hline AF & $740.35 \pm 7.98$ & $101.87 \pm 1.60$ & $20.32 \pm 0.29$ \\
\hline
\end{tabular}

Values are means of triplicate determination \pm Standard deviation; where QE, GAE and AE are quercetin, gallic acid, and atropine equivalents respectively. ESB; ethanol stem bark extract of Milicia excelsa, HF; n-hexane, EAF; ethyacetate, BF; n-butanol and AF; aqeuous fractions of Milicia excelsa stem bark extract 


\subsection{Results of Acute Toxicity $\left(\mathrm{LD}_{50}\right)$ of ESB, HF, EAF, $\mathrm{BF}$ and $\mathrm{AF}$}

The $\mathrm{LD}_{50}$ of ESB, HF, EAF, BF and AF were found to be $>5000 \mathrm{mg} / \mathrm{kg}$, per oral in mice.

\subsection{Results of Sedative-hypnotic Experiments}

\subsubsection{Effects of ESB, HF, EAF, BF and AF on Sleep} Latency in Pentobarbital-induced Sleeping Time in Mice

The ESB, HF, EAF significantly $(\mathrm{p}<0.05)$ at all the doses of 75, 125 and $250 \mathrm{mg} / \mathrm{kg}$, p.o shortened the sleep latency, AF significantly $(\mathrm{p}<0.05)$ shortened the sleep latency at 125 and $250 \mathrm{mg} / \mathrm{kg}$, p.o. when compared to the vehicle treated control group. However, $\mathrm{BF}$ at all the doses used did not show any significant $(p>0.05)$ reduction on sleep latency when compared to the vehicle treated control group. Diazepam, a positive control group at $2 \mathrm{mg} / \mathrm{kg}$, i.p. significantly $(p<0.05)$ reduced the sleep latency when compared to the vehicle treated control group in pentobarbital-induced sleeping time in mice. The result is presented in Figure 1.

\subsubsection{Effects of ESB, HF, EAF, BF and AF on Sleep} Duration in Pentobarbital-induced Sleeping Time in Mice

The ESB, EAF, BF and AF at all the doses used significantly $(\mathrm{p}<0.05)$ and dose dependently prolonged the sleep duration when compared to the vehicle treated control group. The HF showed dose dependent increase in sleep duration but only significant $(\mathrm{p}<0.05)$ at 125 and 250 $\mathrm{mg} / \mathrm{kg}$, when compared to the vehicle-treated control group. The positive control drug diazepam (2 $\mathrm{mg} / \mathrm{kg}$, i.p.) also significantly $(p<0.05)$ elongated the sleep duration when compared to the vehicle treated control group in pentobarbital-induced sleeping time in mice. The result is presented in Figure 2.

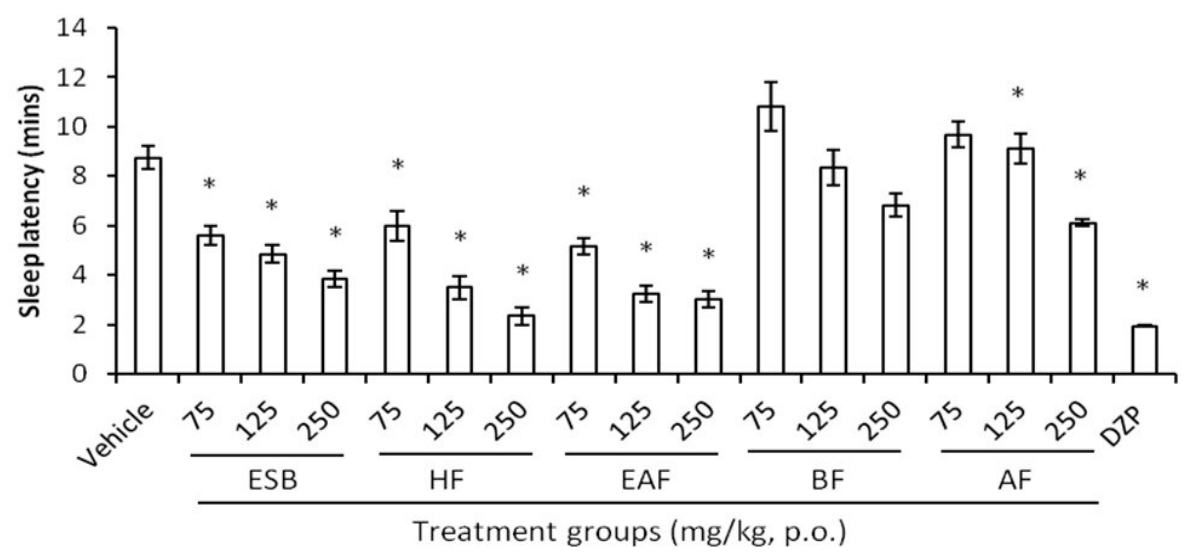

Each bar represents mean \pm SEM. (ANOVA, followed by Dunnett's post hoc), $n=5,{ }^{*} \mathrm{p}<0.05$ when compared to the vehicle-treated control group. ESB; ethanol stem bark extract of Milicia excelsa, HF; n-hexane, EAF; ethyacetate, BF; n-butanol and AF; aqeuous fractions of Milicia excelsa stem bark extract

Figure 1. Sedative effect of ESB, HF, EAF and AF on sleep latency in pentobarbital-induced sleeping time in mice

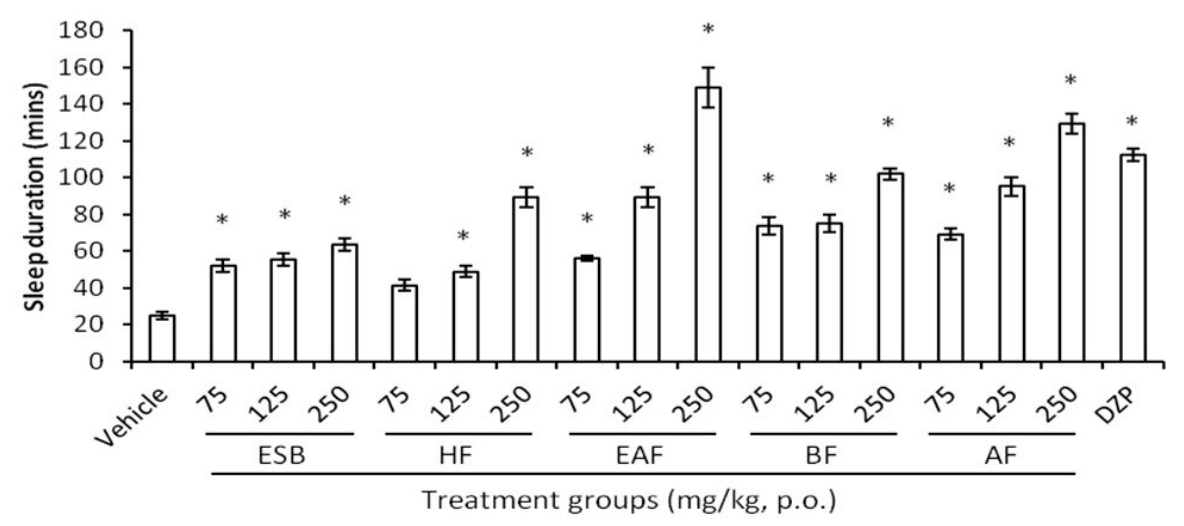

Each bar represents mean \pm SEM. (ANOVA, followed by Dunnett's post hoc), $n=5,{ }^{*} \mathrm{p}<0.05$ when compared to the vehicle-treated control group. ESB; ethanol stem bark extract of Milicia excelsa, HF; n-hexane, EAF; ethyacetate, BF; n-butanol and AF; aqeuous fractions of Milicia excelsa stem bark extract

Figure 2. Sedative effect of ESB, HF, EAF, BF and AF on sleep duration in pentobarbital-induced sleeping time in mice 


\subsubsection{Effects of ESB, HF, EAF, BF and AF on Sleep Latency in Ketamine-induced Sleeping Time in Mice}

The ESB, HF, EAF and BF significantly $(\mathrm{p}<0.05)$ shortened the sleep latency at all the doses of 75, 125 and $250 \mathrm{mg} / \mathrm{kg}$, p.o, AF significantly $(\mathrm{p}<0.05)$ shortened the sleep latency at 125 and $250 \mathrm{mg} / \mathrm{kg}$, p.o. while diazepam $(2 \mathrm{mg} / \mathrm{kg}$, i.p.) significantly $(\mathrm{p}<0.05)$ reduced the sleep latency when compared to the vehicle-treated control group in ketamine-induced sleeping time in mice. The result is presented in Figure 3.

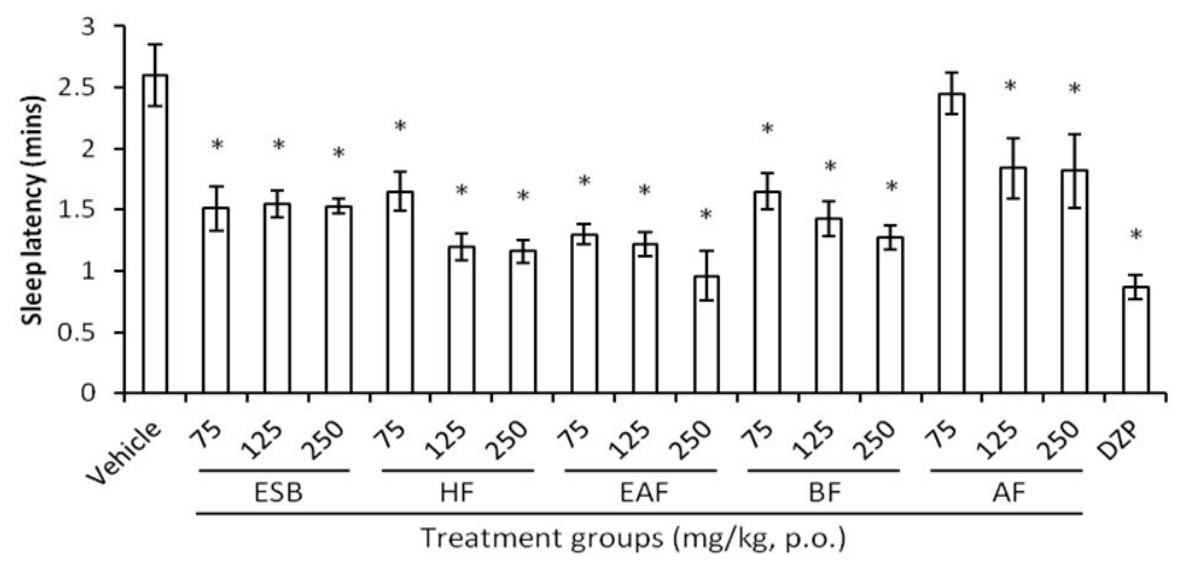

Each bar represents mean \pm SEM. (ANOVA, followed by Dunnett's post hoc), $n=5,{ }^{*} \mathrm{p}<0.05$ when compared to the vehicle-treated control group. ESB ethanol stem bark extract of Milicia excelsa, HF; n-hexane, EAF; ethyacetate, BF; n-butanol and AF; aqeuous fractions of Milicia excelsa stem bark extract

Figure 3. Sedative effect of ESB, HF, EAF, BF and AF on sleep latency in ketamine-induced sleeping time in mice

\subsubsection{Effects of ESB, HF, EAF, BF and AF on Sleep Duration in Ketamine-induced Sleeping Time in Mice}

The ESB, HF, EAF, BF and AF at all the doses used significantly $(\mathrm{p}<0.05)$ and dose dependently prolonged the sleep duration when compared to the vehicle treated control group. The positive control drug diazepam ( $2 \mathrm{mg} / \mathrm{kg}$, i.p.) also significantly $(\mathrm{p}<0.05)$ elongated the sleep duration when compared to the vehicle treated control group in pentobarbital-induced sleeping time in mice. The result is presented in Figure 4.

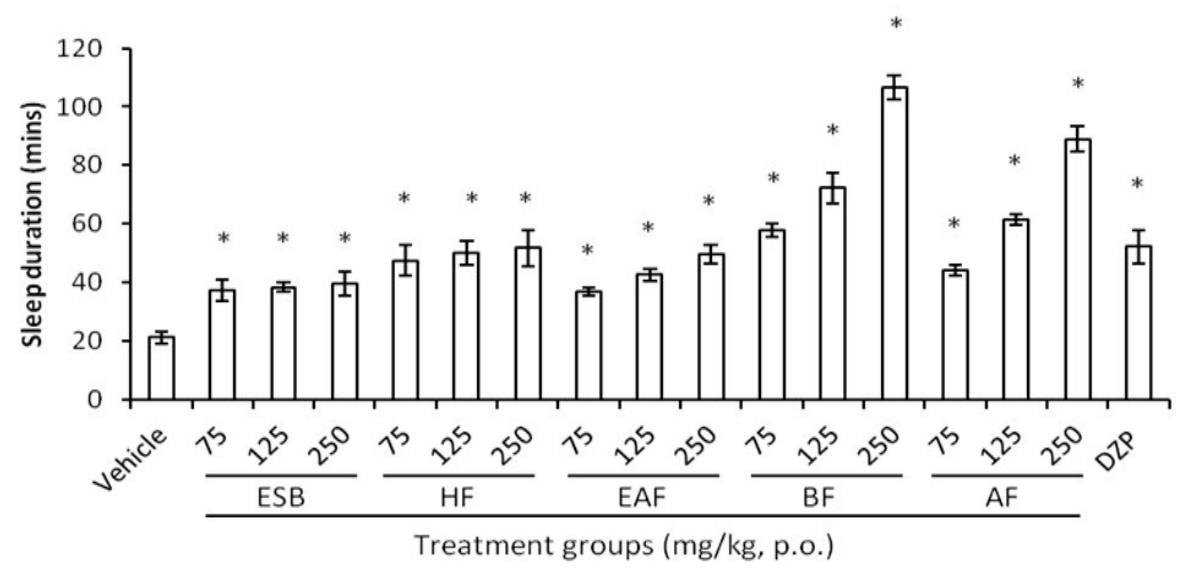

Each bar represents mean \pm SEM. (ANOVA, followed by Dunnett’s post hoc), $n=5,{ }^{*} \mathrm{p}<0.05$ when compared to the vehicle-treated control group. ESB; ethanol stem bark extract of Milicia excelsa, HF; n-hexane, EAF; ethyacetate, BF; n-butanol and AF; aqeuous fractions of Milicia excelsa stem bark extract

Figure 4. Sedative effect of ESB, HF, EAF, BF and AF on sleep duration in ketamine-induced sleeping time in mice 


\section{Discussion}

This study evaluated the acute toxicity $\left(\mathrm{LD}_{50}\right)$ of ESB, HF, EAF, BF and AF using oral route in mice. The study further investigated the sedative-hypnotic effects of the extract and fractions in mice. The findings showed that the extract and fractions were safe and possessed sedative effects in experimental models of sedative-hypnotic tests.

The $\mathrm{LD}_{50}$ of HF, EAF, BF and AF were found to be greater than $5000 \mathrm{mg} / \mathrm{kg}$ indicating the safety of the extract and fractions in mice. Since according to Hayes [33], since no acute toxicity may be considered above $5 \mathrm{~g} / \mathrm{kg}$ body weight.

The pentobarbital-induced sleep test is the most widely used experimental method used for screening sedative-hypnotic agents [34-36], especially those acting via GABAergic system [37, 38]. The ESB and all its fractions in this study reduced sleep latency and prolonged sleeping time in pentobarbital-induced sleep test suggesting that the extract and its various fractions may possess bioactive principles with sedative-hypnotic effect. Although the mechanism of action of ESB and its various fractions were not carried out in this study, but it is well known that barbiturates such as pentobarbital act on the GABA receptor's ionophore complex and allow the opening of chloride channels thus hyperpolarizing the membrane, leading to CNS depression which results in sedation and hypnosis [35]. It is also possible that the sleep modulating effect of ESB and its fractions may also be acting via mixed serotonergic and GABAergic mechanisms to activate the $5-\mathrm{HT}_{2 \mathrm{C}}$ receptors expressed by GABAergic cells in sleep-related brain areas to bring about the reduction in the observed sleep latency and the prolongation of the sleeping time [11, 39].

The ketamine-induced sleep test has been employed to screen medicinal agents with sedative-hypnotic effect [32]. The reduction in sleep latency and potentiation of sleeping time by ESB and all the fractions suggest that these agents may have sedative effects. Ketamine, an antagonist of glutaminergic neurotransmission via the N-Methyl-D-Aspartate (NMDA) excitatory receptor system has been reported to cause sedation with additional $\gamma$-Amino Butyric Acid-A $\left(\mathrm{GABA}_{\mathrm{A}}\right)$ receptor potentiation $[40,41]$. Ketamine has also been reported to prevent the binding of glutamate; the major excitatory neurotransmitter in the CNS to the NMDA receptor, resulting in depressed activities [42, 43]. The observed sedative effects therefore, may be due to the involvement of GABA or NMDA receptor pathway. The finding of our study is in conformity with earlier published data of medicinal agents with sedative-hypnotic effect in ketamine-induced sleeping time [41, 43].

Earlier scientific findings have suggested that flavonoids from medicinal plants may possess sedative effects [44]. Flavonoids have further been reported to bind to the $\mathrm{GABA}_{\mathrm{A}}$ benzodiazepine receptor site thereby resulting in sedative effects [44, 45]. Therefore, the sedative effect of ESB and its various fractions may be attributed to the abundance of total flavonoids, which may act either in additive or synergy with other phytocompounds in the extract and fractions.

\section{Conclusions}

This study concludes that ESB and its fractions may possess sedative-hypnotic potentials. However, further studies may be warranted to elucidate the probable neural mechanism of the observed sedative effect using receptor antagonist and to carry out GABA binding assay to confirm the involvement of GABA in the sedative effect of ESB and its fractions reported in this study, as well as isolate and characterize the sleep promoting bioactive component(s) in ESB and its various fractions.

\section{REFERENCES}

[1] T.I Edewor-Kuponiyi. Plant-Derived Compounds with Potential Sedative and Anxiolytic Activities. Int J Basic and Appl Sci, 2(1): 63-78; 2013.

[2] S Andalib, A Vaseghi, G Vaseghi A.M Naeini. EXCLI J. 10: 192-197; 2011.

[3] R Benco. Diagonsis and treatment of chronic insomnia: A review. Psychiatric services, 56: 332-343; 2005.

[4] C Gottesmann. GABA mechanisms and sleep. Neurosci, 111: 231-239; 2011.

[5] A.J Smith, S.E Tett. Improving the use of benzodiazepines is it possible? A nonsystematic review of interventions tried in the last 20 years. BMC Health Serv Res, 10:321; 2010.

[6] S.M Richey, A.D Krystal. Pharmacological advances in the treatment of insomnia. Curr Pharm Des, 17:1471-1475; 2011.

[7] D Blais, L Petit. Benzodiazepines: dependence and a therapeutic approach to gradual withdrawal. Can Fam Physician, 36:1779-1782; 1990.

[8] D.A Zlott, M Byrne. Mechanisms by which pharmacologic agents may contribute to fatigue. PM\&R, 2:451-455; 2010.

[9] N Hendler, C Cimini, T Ma, D.A Long. A comparison of cognitive impairment due to benzodiazepines and to narcotics. Am J Psychiatry, 137:828-830; 1980.

[10] V.R Askari, V.B Rahimi, A Ghorbani, H Rakhshandeh. Hypnotic Effect of Ocimum basilicum on Pentobarbital-Induced Sleep in Mice. Iran Red Crescent Med J, 18(7): e24261; 2016.

[11] J.H Young, Y.M Kang, BJ Lee, S.Y Chung, KS Kim, I Shim. Sedative-Hypnotic and Receptor Binding Studies of Fermented Marine Organisms. Biomol Ther (Seoul), 23(5): 479-485; 2015. 
[12] M Herrera-Ruiz, C Gutiérrez, J.J Enrique, J Tortoriello, G Miron, I Leon. Central nervous system depressant activity of an ethyl acetate extract from Ipomoea stans roots. J. Ethnopharmacol, 112:243-47; 2007.

[13] Ofori DA. Milicia excelsa (Welw.) C.C. Berg. In: Louppe D, Oteng-Amoako AA, Brink M. (Editors). Prota 7(1): Timbers/Bois d'oeuvre 1. [CD-Rom]. PROTA, Wageningen, Netherlands; 2007.

[14] J.O Areola, O.O Babalola, O.R Ilesanmi, O.O Oyedapo. Toxicity Studies of the Ethanolic Stem- Bark Extract of Milicia excelsa (Welw.) C. C. Berg in Wistar Rats. Am J Biochem, 5(6): 131-137; 2015.

[15] J.A Ibrahim, I Muazzam, I.A Jegede, O.F Kunle, J.I Okogun. Ethno-medicinal plants and methods used by Gwandara tribe of Sabo Wuse in Niger State, Nigeria, to treat mental I illness. Afr. J. Tradit. Complement. Altern. Med, 4:211-8; 2007.

[16] O.M Wahab. Ethnomedicinal antiepileptic plants used in parts of Oyo and Osun States, Nigeria. Bot Res Int, 8(4):77-81; 2015.

[17] M.A Sonibare, M.O Soladoye, T.O Subuloye. Ethnobotanical survey of anti-psychotic plants in Lagos and Ogun States of Nigeria. Eur. J. Sci. Res, 19:634- 644; 2008.

[18] L.A Akinpelu, M.A Akanmu, E.M Obuotor. Antipsychotic Effects of Ethanol Leaf Extract and Fractions of Milicia excelsa (Moraceae) in Mice. J Pharm Res Int, 22(6): 1-10; 2018.

[19] L.A Akinpelu, M.A Akanmu, E.M Obuotor. Anticonvulsant Effects of Ethanol Leaf Extract and Fractions of Milicia excelsa (Moraceae) in Mice. J Pharm Res Int, 23(4): 1-11; 2018.

[20] L.A Akinpelu, O.M Aiyelero G Olayiwola. Ethanol leaf extract of Milicia excelsa mitigates anxiety and depressive-like behaviours induced by acute restraint stress in mice. GSC Biol Pharm Sci, 6(2), 30-39; 2019.

[21] L.A Akinpelu, O.M Aiyelero, I.J Olawuni, G.E Ogundepo, $\mathrm{G}$ Olayiwola. Anti-amnesic and Cognitive Enhancing Effects of Ethanol Leaf Extract of Milicia Excelsa (Moraceae) in Mice. Int J Neurosci Behav Sci, 7(1): 1-11; 2019.

[22] S.O Udegbunam, T.O Nnaji, R.I Udegbunam, J.C Okafor, I Agbo. Evaluation of herbal ointment formulation of Milicia excelsa (Welw) C.C Berg for wound healing. Afr J Biotechnol, 12:3351-3359; 2013.

[23] O.A Olajide, O.T Kolawole, T.R Fagbohun, F.F Ajayi. Evaluation of the anti-inflammatory properties of Chlorophora excelsa stem bark extract. J. Pharm Biol, 43:746-748; 2005.

[24] M.A Adebayo, A.O Adedokun, L.A Akinpelu, P.O Okafor. Evaluation of anti-diarrheal activity of methanol root bark of Milicia excelsa (Welw) CC Berg (Moraceae) in rats. Drug Res, 69:439-444; 2019.

[25] W. Waldegrave. Council Directive 86/609/EEC of 24 November 1986 on the approximation of laws, regulations and administrative provisions of the member states regarding the protection of animals used for experimental and other scientific purposes. Pg1-46.
[26] Zhishen J, Mengcheng T, Jianming W. The determination of flavonoid contents in mulberry and their scavenging effects on superoxide radicals. Food Chem, 64(4), 555-559; 1999.

[27] Siddhuraju P, Becker K. Antioxidant properties of various solvent extracts of total phenolic constituents from three different agroclimatic origins of drumstick tree (Moringa oleifera Lam.) leaves. J Agr Food Chem, 51(8):2144-2155; 2003.

[28] AfifyAel-M, El-Beltagi HS, El-Salam SM, Omran AA. Biochemical changes in phenols, flavonoids, tannins, vitamin $\mathrm{E}, \beta$-carotene and antioxidant activity during soaking of three white sorghum varieties. Asian Pac J Trop Biomed, 2(3), 203-9; 2012.

[29] Shamsa F, Monsef H, Ghamooshi R, Verdian-rizi M. Spectrophotometric determination of total alkaloids in some Iranian medicinal plants. Thai J Pharm Sci, 32:17-20, 2003.

[30] OECD. Guidelines for Testing of Chemicals: Guideline 425: Acute Oral Toxicity. Paris, France. The Organization of Economic Co-operation and Development, 2008.

[31] A Ghorbani, N.J Youssofabad, H Rakhshandeh. Effect of Viola tricolor on pentobarbital-induced sleep in mice. Afr J Pharm and Pharmacol, 6(35): 2600-2606; 2012.

[32] A.O Aderibigbe, I.O Adeyemi, O.I Agboola. Central Nervous System Depressant Properties of Treculia africana Decne. Ethnobot Leaflets, 14: 108; 2010.

[33] A.W Hayes. Guidelines for acute oral toxicity testings. In: Principles and Methods of Toxicity, 2nd Edn. Raven Press Ltd., New York. (Table 4):185; 1989.

[34] H Rakhshandah, M.T Shakeri, M.R Ghasemzadeh. Comparative hypnotic effect of Rosa damascena fractions and Diazepam in Mice. Iran. J. Pharm. Res, 2010:193-7.

[35] A Hosseini, A Ghorbani, H.R Sadeghnia, A Rajabian, H Rakhshandeh. Potentiating effects of Lactuca serriola on pentobarbital-induced sleep. Res Opin Anim Vet Sci, 4(11):601-7; 2014.

[36] H Rakhshandeh, H.R Sadeghnia, A Ghorbani. Sleep-prolonging effect of Coriandrum sativum hydro-alcoholic extract in mice. Nat Prod Res, 26(22):2095-8; 2012.

[37] Y Ma, h Ma, J.S Eun, S.Y Nam, Y.B Kim, J.T Hong et al. Methanol extract of Longanae Arillus augments pentobarbital-induced sleep behaviors through the modification of GABAergic systems. J Ethnopharmacol, 22;245-250; 2009.

[38] S.M Cho, M Shimizu, C.J Lee, D.S Han, C.K Jung, J.H Jo et al. Hypnotic effects and binding studies for GABA(A) and 5-HT(2C) receptors of traditional medicinal plants used in Asia for insomnia. J Ethnopharmacol, 132;225-232; 2010.

[39] S Liu, M.J Bubar, M.F Lanfranco, G.R Hillman, K.A Cunningham. Serotonin2C receptor localization in GABA neurons of the rat medial prefrontal cortex: implications for understanding the neurobiology of addiction. Neurosci, 146;1677-1688; 2007.

[40] O Henschel, K.E Gipson, A Bordey. GABAA receptors, anesthetics and anticonvulsants in brain development. CNS Neurol Disord Drug Targets, 7:211-24; 2008. 
[41] P Nagakannan, B.D Shivasharan, V.P Veerapur, S Boreddy. Thippeswamy BS (2011). Sedative and antiepileptic effects of Anthocephalus cadamba Roxb. in mice and rats. Indian $\mathrm{J}$ Pharmacol, 43(6): 699-702.

[42] L.P Posner. Injectable anesthetics. In: Papich, M.G. and Riviere, J.E., editors. Veterinary Pharmacology and Therapeutics. 10th ed. Wiley-Blackwell, Iowa, USA. P 247-280; 2017.

[43] H.G Mikail, D.D Akumka, M Adamu, A.U Zaifada. Evaluation of phytochemical constituents and sedative-hypnotic activity of the methanol leaf extract of Ficus exasperata in mice, Vet World, 12(6): 830-833; 2019.

[44] A.K Jager, L. Saaby. Flavonoids and the CNS. Molecules, 16(2):1471-1485; 2011

[45] M. Shahed. Al-Mahmud, SMM Lina. Evaluation of sedative and anxiolytic activities of methanol extract of leaves of Persicaria hydropiperin mice. Clin Phytosci. 3:20; 2017. 